\title{
PURIFICATION AND CHARACTERIZATION OF A LOW MOLECULAR WEIGHT XYLANASE FROM SOLID-STATE CULTURES OF ASPERGILLUS FUMIGATUS FRESENIUS
}

\author{
Claudio Henrique Cerri e Silva'; Jurgen Puls²; Marcelo Valle de Sousa ${ }^{3}$; \\ Edivaldo Ximenes Ferreira Filho ${ }^{1^{*}}$
}

${ }^{1}$ Laboratório de Enzimologia, Departamento de Biologia Celular, Universidade de Brasília, Brasília, DF, Brasil. ${ }^{2}$ Institut für Holzchemie, Hamburg, Germany. ${ }^{3}$ Centro Brasileiro de Serviços e Pesquisas em

Proteínas, Departamento de Biologia Celular, Universidade de Brasília, Brasília, DF, Brasil

\begin{abstract}
A xylan-degrading enzyme (xylanase II) was purified to apparent homogeneity from solid-state cultures of Aspergillus fumigatus Fresenius. The molecular weight of xylanase II was found to be 19 and $8.5 \mathrm{kDa}$, as estimated by SDS-PAGE and gel filtration on FPLC, respectively. The purified enzyme was most active at $55^{\circ} \mathrm{C}$ and $\mathrm{pH}$ 5.5. It was specific to xylan. The apparent $\mathrm{K}_{\mathrm{m}}$ and $\mathrm{V}_{\max }$ values on soluble and insoluble xylans from oat spelt and birchwood showed that xylanase II was most active on soluble birchwood xylan. Studies on hydrolysis products of various xylans and xylooligomers by xylanase II on HPLC showed that the enzyme released a range of products from xylobiose to xylohexaose, with a small amount of xylose from xylooligomers, and presented transferase activity.
\end{abstract}

Key words: xylan, xylanase, Aspergillus fumigatus

\section{INTRODUCTION}

Xylan is one of the major constituents of lignocellulosic materials, accounting for approx. $35 \%$ of the total dry weight of higher plants (12). The basic molecular structure of xylan is a linear backbone comprised of $\beta$-1,4-linked D-xylopyranose residues which, depending on the origin and method of extraction, may be substituted with branches containing mainly acetyl, arabinosyl and glucuronosyl residues $(2,12)$. The complete cleavage of the complex structure of xylan molecules requires the combined action of $\beta$-xylanase (EC 3.2.1.8) and $\beta$-xylosidase (EC 3.2.1.37) with debranching enzymes such as $\alpha$-arabinofuranosidase
(EC 3.2.1.55), acetyl xylan esterase (EC 3.1.1.6) and $\alpha$-glucuronidase (EC 3.2.1) $(2,22)$. There is a great interest in the enzymatic hydrolysis of xylan because of possible applications in ruminal digestion, waste treatment, fuel and chemical production, and paper manufacture $(2,12,27)$. This work reports the purification and some properties of xylanase II from solid-state cultures of the fungus Aspergillus fumigatus Fresenius.

\section{MATERIALS AND METHODS}

Organism and Enzyme Production. $A$. fumigatus Fresenius was isolated from a hot fountain in Brasil (Caldas Novas, Goiás) and identified by

\footnotetext{
* Corresponding author. Mailing address: Laboratório de Enzimologia, Departamento de Biologia Celular, Universidade de Brasília, CEP 70910-900, Brasília, DF, Brasil
} 
specialists of the Mycology Department from the Universidade Federal de Pernambuco (Brazil). For production of xylanase activity, A. fumigatus Fresenius was cultured at $42^{\circ} \mathrm{C}$ for 7 days in a solidstate medium containing wheat bran (27). After the growth procedure, the contents of the flasks were extracted with $750 \mathrm{ml}$ of $25 \mathrm{mM}$ sodium acetate buffer, $\mathrm{pH} 5.0$ and placed under shaking (120 rpm) at room temperature for $3 \mathrm{~h}$. The resulting crude extract was centrifuged for $30 \mathrm{~min}$ at $10,400 \mathrm{~g}$ and $5^{\circ} \mathrm{C}$, filtered and stored at $5^{\circ} \mathrm{C}$ for subsequent use as source of xylanase activity.

Enzyme Assays. Xylanase activity was determined by mixing $25 \mu$ l of enzyme solution with $50 \mu \mathrm{l}$ of oat spelt xylan $(3.0-50 \mathrm{mg} / \mathrm{ml})$ in $100 \mathrm{mM}$ sodium acetate buffer, $\mathrm{pH} 5.0$ at $50^{\circ} \mathrm{C}$ for $30 \mathrm{~min}$. The release of reducing sugar was measured using the dinitrosalicylic reagent method $(19,24)$. Xylanase activity was expressed as $\mu \mathrm{mol}$ reducing sugar formed $\mathrm{min}^{-1} \mathrm{ml}^{-1}$ enzyme solution, i.e., as IU $\mathrm{ml}^{-1}$ and IU $\mathrm{mg}^{-1}$ protein. B-Glucanase, carboxymethyl-cellulase and $\beta$-mannanase assays were performed in the conditions as described above. The activity against filter paper was measured as described by Mandels et al. (18). $\beta$-Xylosidase, $\alpha$ arabinofuranosidase, $\beta$-glucosidase and $\beta$ mannosidase activities were determined as reported elsewhere (24). For the kinetic experiments, soluble and insoluble samples from oat spelt and birchwood xylans were used as substrates in a concentration range of $0.05-8.0 \mathrm{mg} / \mathrm{ml}$. The substrates were prepared as described by Filho et al. $(11,13) . \mathrm{K}_{\mathrm{m}}$ and $\mathrm{V}_{\max }$ Values were estimated from MichaelisMenten equation with a non-linear regression data analysis program (17). The determination of optimum temperature of xylanase II was carried out in the temperature range of 30 to $90^{\circ} \mathrm{C}$ in $100 \mathrm{mM}$ sodium acetate buffer, $\mathrm{pH}$ 5.0. To determine the optimum $\mathrm{pH}$ of xylanase II activity at $50^{\circ} \mathrm{C}$, the range was from 3.0 to 8.0. Mcllvaine type buffer systems were adjusted to the same ionic strength with $\mathrm{KCl}$ (7). The temperature stability of xylanase II was determined by pre-incubating the enzyme at $55^{\circ} \mathrm{C}$. At various time periods, aliquots were withdrawn and the residual activity was measured under standard conditions.

Protein Concentration. Protein concentration was measured by the method of Petterson (20), using bovine serum albumin as standard.

Enzyme Purification. All purification steps were carried out at $4^{\circ} \mathrm{C}$ unless otherwise specified. The crude extract was concentrated by ultrafiltration using an Amicon system with a $10 \mathrm{kDa}$ cut-off point membrane (PM 10). Aliquots of the ultrafiltrate were fractionated by gel filtration on Sephadex G-50 (2.3 x $42 \mathrm{~cm}$ ), pre-equilibrated with $100 \mathrm{mM}$ sodium acetate buffer, $\mathrm{pH}$ 5.0. Fractions of $4.0 \mathrm{ml}$ were collected at a flow rate of $12 \mathrm{ml} / \mathrm{h}$. Fractions with xylanase activity were pooled, dialyzed against 10 $\mathrm{mM}$ sodium phosphate buffer, $\mathrm{pH}$ 7.2, and loaded onto a Econo-Pac CHT-II column $(1.3 \times 4.1 \mathrm{~cm})$, equilibrated with the same buffer. Fractions of 2.0 $\mathrm{ml}$ were collected at a flow rate of $30 \mathrm{ml} / \mathrm{h}$ by washing the column with buffer followed by a linear gradient of sodium phosphate buffer $(10-400 \mathrm{mM}), \mathrm{pH} 7.2$, and those with xylanase activity were pooled and dialyzed against $20 \mathrm{mM}$ sodium phosphate buffer, $\mathrm{pH}$ 7.0. The dialyzed solution was applied to a EconoPac High Q column $(1.3 \times 4.1 \mathrm{~cm})$ pre-equilibrated with $20 \mathrm{mM}$ sodium phosphate buffer, $\mathrm{pH}$ 7.0. The column was washed with the same buffer and eluted with a linear gradient of $\mathrm{NaCl}(0-1 \mathrm{M})$. Fractions of $2.0 \mathrm{ml}$ were collected at a flow rate of $120 \mathrm{ml} / \mathrm{h}$. Fractions containing xylanase activity were pooled and dialyzed against $20 \mathrm{mM}$ sodium phosphate buffer, $\mathrm{pH}$ 6.5. Finally, further enzyme purification was performed in the same column equilibrated with $20 \mathrm{mM}$ sodium phosphate buffer, $\mathrm{pH} 6.5$ at a flow rate of $120 \mathrm{ml} / \mathrm{h}$. The residual protein was eluted with a $\mathrm{NaCl}$ linear gradient from 0 to $1 \mathrm{M}$. Fractions corresponding to xylanase activity were pooled, concentrated by freeze-drying and stored for later use at $4^{\circ} \mathrm{C}$.

Electrophoresis. Sodium dodecyl sulfatepolyacrylamide gel electrophoresis (SDS-PAGE) was carried out as described by Laemmli (16) using 12\% gels. After electrophoresis, protein bands were silver stained by the method of Blum et al. (3). The molecular weight of xylanase II was estimated by SDS-PAGE and gel filtration on a fast protein performance liquid chromatography system (FPLC) using MW marker kits from Sigma Chemical Co., USA. The FPLC column (Superose 12) was equilibrated with $20 \mathrm{mM}$ sodium phosphate buffer, $\mathrm{pH}$ 7.0. The elution was performed at a flow rate of $30 \mathrm{ml} / \mathrm{h}$.

Hydrolysis Products. The reaction mixture containing $100 \mu \mathrm{l}$ of enzyme solution $(20 \mu \mathrm{g} / \mathrm{ml})$ and $500 \mu \mathrm{l}$ of $0.2 \%$ xylan in distilled water was incubated for $16 \mathrm{~h}$ at $28^{\circ} \mathrm{C}$ with shaking at $100 \mathrm{rev} . / \mathrm{min}$. The reaction mixture from above was stopped by heating in boiling water and centrifuged at 3,000 $\mathrm{x}$ g for 5 
min. The determination of hydrolysis products was made by high performance anion exchange chromatography coupled with pulsed amperometric detection (Dionex Corp., USA), as described previously $(11,22,23)$. The analysis of the hydrolysis products of xylooligomers by xylanase IIa was also performed as described above. However, the hydrolysis of xylooligomers was determined following 1 to $2 \mathrm{~h}$ of incubation at $40^{\circ} \mathrm{C}$.

Chemicals. Oat spelt xylan and birchwood xylan, were from Sigma Chemical Co., USA. All other chemicals were analytical grade reagents. Deacetylated and acetylated xylans were obtained by dimethylsulfoxide extraction (DMSO) of beechwood and wheat straw holocelluloses, respectively (23). Xylan extracted by $\mathrm{HCl}$ from the seaweed Palmaria palmata was a gift from Maria G. Tuohy (University College Galway, Ireland). Xylooligosaccharides were prepared as described before (21).

\section{RESULTS AND DISCUSSION}

A xylanase was isolated from the xylandegrading enzyme system of $A$. fumigatus Fresenius, and purified to apparent homogeneity by a combination of ultrafiltration and chromatographic procedures. The purification steps of xylanase II are summarized in Table 1. The ultrafiltration experiment showed that a xylanase activity was found to be present in the ultrafiltrate. For further purification, the ultrafiltrate was subjected to gel filtration chromatography on Sephadex G-50 (Fig. 1). The sample elution resulted in the separation of two peaks

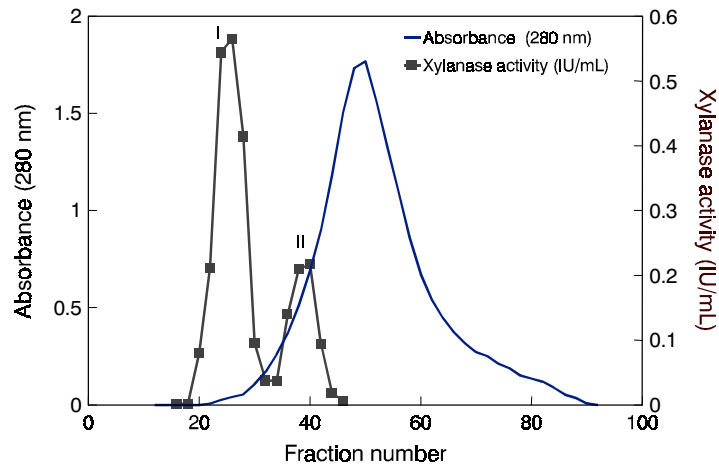

Figure 1. Fractionation on Sephadex G-50 of A. fumigatus Fresenius ultrafiltrate. For experimental details see text.

of xylanase activity (I and II). The second peak, designated xylanase II, was used for further purification by hydroxylapatite and anion-exchange chromatographies (results not shown). In both purification procedures, xylanase II was eluted in the pre-gradient wash fractions. The purification step procedures provided an apparently homogeneous preparation of xylanase II, as determined by sodium dodecyl sulphate-polyacrylamide gel electrophoresis (SDS-PAGE). The enzyme migrated as a single 19 $\mathrm{kDa}$ band on SDS-PAGE stained with silver nitrate (Fig. 2). However, its apparent size by gel filtration was $8.5 \mathrm{kDa}$, indicating a physical interaction between the enzyme and chromatography resin (result not shown). This is in agreement with the results obtained for xylan-degrading enzymes from T. harzianum, T. reesei, A. oryzae, A. fumigatus VTTD-71002 and Bacillus sp $(1,8,26)$. A small amount of carbohydrate was found when the purified

Table 1. Summary of the purification of $\beta$-xylanase II from A. fumigatus Fresenius.

\begin{tabular}{|c|c|c|c|c|c|}
\hline Step & $\begin{array}{l}\text { Total protein } \\
(\mathrm{mg})\end{array}$ & $\begin{array}{l}\text { Total activity } \\
\text { (IU) }\end{array}$ & $\begin{array}{c}\text { Specific activity } \\
\left.(\mathrm{IU} \mathrm{mg})^{-1}\right)\end{array}$ & $\begin{array}{l}\text { Yield } \\
(\%)\end{array}$ & $\begin{array}{c}\text { Purification } \\
\text { factor }\end{array}$ \\
\hline Crude Extract & 196.78 & $1,234.0$ & 6.27 & 100 & 1.0 \\
\hline Ultrafiltration & 37.41 & 210.21 & 5.62 & 17.05 & 0.90 \\
\hline Sephadex G-50 & 19.23 & 90.0 & 4.67 & 7.30 & 0.74 \\
\hline Econo-Pac & & & & & \\
\hline CHT-II & 6.13 & 12.0 & 2.0 & 1.0 & 0.31 \\
\hline $\begin{array}{l}\text { Econo-Pac } \\
\text { High Q }\end{array}$ & & & & & \\
\hline $\mathrm{pH} 7.0$ & 2.82 & 6.04 & 2.14 & 0.50 & 0.34 \\
\hline Econo-Pac & & & & & \\
\hline High Q & & & & & \\
\hline pH 6.5 & 0.45 & 3.21 & 7.10 & 0.26 & 1.32 \\
\hline
\end{tabular}






Figure 2. SDS-PAGE (12\%) of ß-xylanase II from A. fumigatus Fresenius stained with silver nitrate. Lane 1, molecular weight standards (from the top): bovine serum albumin (66 kDa), ovalbumin (45 kDa), trypsinogen (24 kDa), B-lactoglobulin (18.4 $\mathrm{kDa})$, lysozyme (14.3 kDa); lane 2, xylanase II.

xylanase II from $A$. fumigatus Fresenius was assayed with the phenol-sulfuric acid method (9). The low yield and fold-purification values obtained for xylanase II from A. fumigatus were probably underestimated. This phenomenon is often described during purification of xylan-degrading enzymes produced by fungi $(10,13,14)$. At least one major and some minor peaks of xylanase activities were also detected in the ultrafiltrate during the purification procedure. Besides, the ultrafiltration procedure retained most of the bulk of xylandegrading activities in the retentate. Fractionation of the retentate by gel filtration, adsorption and ionexchange chromatography techniques showed the presence of, at least, nine different xylanase activities. These enzymes may act synergistically with xylanase II to effect the complete hydrolysis of xylan (10).

Xylanase II was optimally active at $\mathrm{pH} 5.5$ and $55^{\circ} \mathrm{C}$. This optimum $\mathrm{pH}$ value was also described for xylanases from A. sydowii MG49 and A. niger $(15,25)$. The purified enzyme showed a half-life of 80 min. when incubated at $55^{\circ} \mathrm{C}$ and $\mathrm{pH} 7.0$ (Fig. 3). The purified enzyme was not active on CMC, filter paper, para-nitrophenyl $\beta$-D-xylopyranoside, paranitrophenyl $\alpha$-L-arabinofuranoside, para-nitrophenyl $\beta$-D-mannopyranoside, para-nitrophenyl $\beta$-Dglucopyranoside, $\beta$-laminarin and $\beta$-mannan. In addition, the enzyme was specific for xylan. The $\mathrm{K}_{\mathrm{m}}$ values for soluble xylan from oat spelt were much higher than the insoluble one (Table 2). This might suggests a steric hindrance due to the presence of side-chains groups in soluble xylan. Conversely, the hydrolysis of soluble birchwood xylan by xylanase II was more effective than when the enzyme was incubated with the insoluble xylan, suggesting that the presence of a particular type of substituent (acetyl group) in the vicinity would be a requirement for the action of xylanase II (4). The hypothesis of the substituents are probably situated in regions of the polysaccharide distant from the unsubstituted portions can not be discarded. Debranching activity was also found in some xylanases (2). The $\mathrm{K}_{\mathrm{m}}$ values for xylanase II were lower than the values found for xylanases from $F$. oxysporum and $P$. capsulatum (5, $6,11)$.

Table 2. Some kinetic properties of the purified B-xylanase II produced by $A$. fumigatus Fresenius.

\begin{tabular}{lcc}
\hline Substrate & $\mathrm{K}_{\mathrm{m}}(\mathrm{mg} / \mathrm{ml})$ & $\mathrm{V}_{\max }(\mathrm{IU} / \mathrm{ml})$ \\
\hline Soluble oat spelt xylan & 5.72 & 2.34 \\
Insoluble oat spelt xylan & 3.01 & 1.41 \\
Soluble birchwood xylan & 2.19 & 1.55 \\
Insoluble birchwood xylan & 5.19 & 1.89 \\
\hline
\end{tabular}

The predominant hydrolysis products of birchwood and deacetylated xylans by xylanase II ranged from xylobiose to xylohexaose (Table 3). Xylanase IIa was not able to release xylose from xylan molecules, suggesting an endomechanism. Xylan from seaweed (Palmaria palmata), a $\beta$ 1,3;1,4-linked polymer, was degraded to a mixture of xylobiose and xylotriose, while xylobiose to xylopentaose were released from oat spelt xylan. The high proportion of acetyl groups linked to xylose residues in acetylated xylan was probably a steric obstacle to xylanase II activity (12). The purified xylanase did not show any activity against xylotriose and xylotetraose. The hydrolytic capacity of $\beta-$ xylanase increased with increasing chain length of xylooligomers (Table 3). Xylose, xylobiose and xylotetraose were removed from xylopentaose. The enzyme showed transferase activity when incubated with xylohexaose. The purified enzyme was able to produce higher molecular weight transfer products. Transferase activity has been reported for some other xylan-degrading enzymes from Aspergillus $(1,5)$.

In conclusion, the fungus $A$. fumigatus Fresenius produces multiple forms of xylanases. The purified xylanase II is a $19 \mathrm{kDa}$ enzyme with an acidic 
Table 3. Hydrolysis products of xylans and xylooligomers by xylanase II from $A$. fumigatus Fresenius. Abbreviations: X1, xylose; X2, xylobiose; X3, xylotriose; X4, xylotetraose; X5, xylopentaose; X6, xylohexaose; ND, not detected.

\begin{tabular}{ll}
\hline Substrate & Hydrolysis Products \\
\hline Oat spelt xylan & $\mathrm{X} 2, \mathrm{X} 3, \mathrm{X} 4, \mathrm{X} 5$ \\
Birchwood xylan & $\mathrm{X} 2, \mathrm{X} 3, \mathrm{X} 4, \mathrm{X} 5, \mathrm{X} 6$ \\
Acetylated xylan & $\mathrm{ND}$ \\
Deacetylated xylan & $\mathrm{X} 2, \mathrm{X} 3, \mathrm{X} 4, \mathrm{X} 5, \mathrm{X} 6$ \\
Seaweed xylan $^{\text {Xilotriose }}$ & $\mathrm{X} 2, \mathrm{X} 3$ \\
Xilotriose $^{\mathrm{b}}$ & $\mathrm{ND}$ \\
Xylotetraose $^{\mathrm{a}}$ & $\mathrm{ND}$ \\
Xylotetraose $^{\mathrm{b}}$ & $\mathrm{ND}$ \\
Xylopentaose $^{\mathrm{a}}$ & $\mathrm{ND}$ \\
Xylopentaose $^{\mathrm{b}}$ & $\mathrm{X} 1, \mathrm{X} 2, \mathrm{X} 4$ \\
Xylohexaose $^{\mathrm{a}}$ & $\mathrm{X} 1, \mathrm{X} 2, \mathrm{X} 4$ \\
Xylohexaose $^{\mathrm{b}}$ & $\mathrm{X} 3, \mathrm{X} 4, \mathrm{X} 5$ \\
\hline
\end{tabular}

${ }^{\mathrm{a}}$ One hour incubation; ${ }^{\mathrm{b}}$ two hours incubation

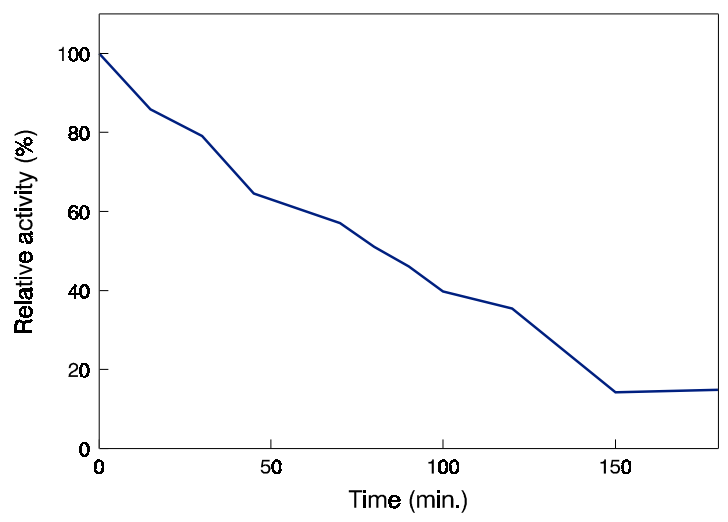

Figure 3. Stability of purified xylanase II from $A$. fumigatus Fresenius at $55^{\circ} \mathrm{C}$.

optimum $\mathrm{pH}$ and thermostability. It seems to belong to the group of specific xylanases with an endo-acting mechanism.

\section{ACKNOWLEDGEMENTS}

This work was supported by research grants from the International Foundation for Science (IFS, Sweden), PACDT III (CNPq, Brazil) and Fundação de Apoio à Pesquisa do Distrito Federal (FAPDF, Brazil). The technical assistance of Annegret Borchmann on Dionex system is gratefully acknowledged.

\section{RESUMO}

\section{Purificação e caracterização de uma xilanase de baixo peso molecular de culturas de estado sólido de Aspergillus fumigatus Fresenius}

Uma enzima xilanolítica (xilanase II) foi purificada a partir de culturas de estado sólido de Aspergillus fumigatus Fresenius. O peso molecular de xilanase II foi estimado em 19 e 8,5 kDa por SDSPAGE e FPLC, respectivamente. A enzima purificada apresentou maior atividade a $55^{\circ} \mathrm{C}$ e pH 5,5 , além de hidrolisar especificamente xilana. Os valores aparentes de $\mathrm{K}_{\mathrm{m}}$ e $\mathrm{V}_{\max }$ de xilanas solúveis e insolúveis, isoladas de cereal e madeira, mostrou que xilanase IIa foi mais ativa em xilana solúvel de madeira. Estudos sobre produtos de hidrólise de xilanas e xilooligômeros por xilanase II em HPLC revelou que a enzima liberou uma variedade de xilooligômeros (xilobiose-xilohexose) e uma pequena quantidade de xilose a partir de xilooligômeros, apresentando atividade de transferase.

Palavras-chave: xilana, xilanase de baixo peso molecular, purificação da enzima, caracterização da enzima.

\section{REFERENCES}

1. Bailey, M.J.; Puls, J.; Poutanen, K. Purification and properties of two xylanases from Aspergillus oryzae. Biotechnol. Appl. Biotechnol., 13: 380-389, 1991.

2. Bajpai, P. Microbial xylanolytic enzyme system: properties and applications. Adv. Appl. Microbiol., 43: 141- 194, 1997.

3. Blum, H.; Beier, H.; Gross, B. Improved silver staining of plant proteins, RNA and DNA in polyacrilamide gels. Electrophoresis, 8: 93-99, 1987.

4. Coughlan, M.P.; Tuohy, M.G.; Filho, E.X.F.; Puls, J.; Claeyssens, M.; Vrsanská, M.; Hughes, M.M. Enzymological aspects of microbial hemicellulases with emphasis on fungal. In: Coughlan, M.P.; Hazlewood, G.P. (eds). Hemicellulose and hemicellulases. Portland Press, London, 1993, p. 53-84.

5. Christakopoulos, P.; Kekos, D.; Macris, B.J.; Claeyssens, M.; Bhat, M.K. Purification and characterization of a major xylanase with cellulase and transferase activities from Fusarium oxysporum. Carbohydr. Res., 289: 91-104, 1996a.

6. Christakopoulos, P.; Nerinckx, W.; Kekos, D.; Macris, B. J.; Claeyssens, M. Purification and characterization of two low molecular mass alkaline xylanases from Fusarium oxysporum F3. J. Biotechnol., 51: 181-189, 1996b.

7. Dawson, R. M. C.; Elliott, D. C; Eliott, W. H.; Jones, K. M. pH, Buffers, and physiological media. In: Dawson, R. M. C.; Elliott, D. C.; Eliott, W. H.; Jones, K. M. (eds). Data for biochemical research. University Press, Oxford, 1969, p. 501.

8. Dey, D.; Hinge, J.; Shendye, A.; Rao, M. Purification and properties of extracellular endoxylanases from alkalophilic thermophilic Bacillus sp. Can. J. Microbiol., 38: 436-442, 1991. 
9. Dubois, M.; Giles, K.; Hamilton, J. K.; Rebers, P. A.; Smith, F. Colorimetric method for determination of sugars and related substrates. Anal. Chem., 28: 350-356, 1956.

10. Filho, E. X. F.; Puls, J.; Coughlan, M. P. Physiochemical and catalytic properties of a low molecular weight endo-1,4- $\beta$ D-xylanase from Myrothecium verrucaria. Enzyme Microb. Technol. 15: 535-540, 1993a.

11. Filho, E. X. F.; Puls, J.; Coughlan, M. P. Biochemical characteristics of two endo- $\beta-1,4-x y l a n a s e s$ produced by Penicillium capsulatum. J. Industr. Microbiol. 11: 171-180, 1993b.

12. Filho, E. X. F. The xylan-degrading enzyme system. Brazilian J. Med. Biol. Res. 27: 1093-1109, 1994.

13. Filho, E. X. F.; Puls, J.; Coughlan, M. P. Purification and characterization of two arabinofuranosidases from solid-state cultures of Penicillium capsulatum. Appl. Environ. Microbiol. 62: 168-173, 1996.

14. Gomez de Segura, B.; Fevre, M. Purification and characterization of two 1,4- $\beta$-xylan endohydrolases from the rumen fungus Neocallimastix frontalis. Appl. Environ. Microbiol. 59: 3654-3660, 1993.

15. Ghosh, M.; Nanda, G. Purification and some properties of a xylanase from Aspergillus sydowii MG49. Appl. Environ. Microbiol., 60: 4620-4623, 1994.

16. Laemmli, U.K. Cleavage of structural proteins during the assembly of the head of bacteriophage T4. Nature 227: 680685,1970

17. Leatherbarrow, R.J. Enzifitter manual. Biosoft, London, 1987, p. $13-42$

18. Mandels, M.; Andreotti, R.; Roche, C. Measurement of saccharifying cellulase. Biotechnol. Bioeng. Symp. 16: 2133, 1976.
19. Miller, G.L. Use of dinitrosalicylic acid reagent for the determination of reducing sugar. Anal. Chem. 31: 426-428, 1959.

20. Petterson, G.L.A simplification of the protein assay method of Lowry et al. which is more applicable. Anal. Biochem. 83: 243-249, 1977.

21. Puls, J.; Borchmann, A.; Gottschalk, D.; Wiegel, J. Xylose and xylooligomers. Meth. Enzymol. 160: 528-536, 1988.

22. Puls, J.; Poutanen, K. Mechanisms of enzymic hydrolysis of hemicelluloses (xylans) and procedures for determination of the enzyme activity involved. In: Coughlan, M. P. (ed). Enzyme systems for lignocellulose degradation. Elsevier Applied Science, London 1989, p. 151-2165.

23. Puls, J.; Tenkanen, M.; Korte, H.E.; Poutanen, K. Products of beechwood acetyl-4-O-methylglucuronoxylan hydrolysis by a xylanase and an acetylxylanesterase. Enzyme Microb. Technol. 13: 483-486, 1991.

24. Silveira, F.Q.P.; Melo, I.S.; Filho, E.X.F. Carbohydratehydrolysing enzyme activity production by solid-state cultures of Trichoderma harzianum strains. Rev. Microbiol. 28: 152-156, 1997.

25. Wong, K.K.Y.; Tan, L.U.L.; Saddler, J.N. Multiplicity of $\beta$ 1,4-xylanases in microorganisms: function and applications. Microbiol. Revs., 52: 305-317, 1988.

26. Ximenes, F.A.; Silveira, F.Q.P.; Filho, E.X.F. Production of ß-xylosidase activity by Trichoderma harzianum. Curr. Microbiol., 33: 71-77, 1996.

27. Ximenes, F.A.; Fonseca, A.S.; Ximenes, E.A.; Silveira, F.Q.P.; Silva, C.H.C.; Lucena, S. A.; Ribeiro, W. R. C.; Filho, E.X.F. Xylan-degrading enzyme production by solid-state cultures of aerobic fungi. Rev. Microbiol. 5: 22-28, 1997. 